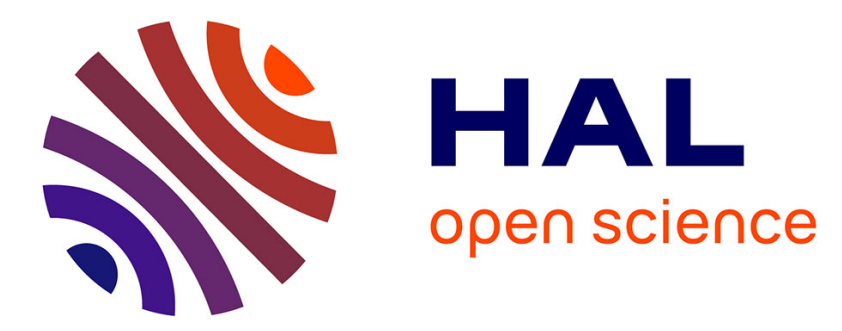

\title{
Ceramic and metal-ceramic nanostructures obtained by reactive ball milling
}

\author{
J. Secondi, R. Yavari
}

\section{To cite this version:}

J. Secondi, R. Yavari. Ceramic and metal-ceramic nanostructures obtained by reactive ball milling. Journal de Physique IV Proceedings, 1993, 03 (C7), pp.C7-1287-C7-1292. 10.1051/jp4:19937198 . jpa-00251831

\section{HAL Id: jpa-00251831 https://hal.science/jpa-00251831}

Submitted on 1 Jan 1993

HAL is a multi-disciplinary open access archive for the deposit and dissemination of scientific research documents, whether they are published or not. The documents may come from teaching and research institutions in France or abroad, or from public or private research centers.
L'archive ouverte pluridisciplinaire HAL, est destinée au dépôt et à la diffusion de documents scientifiques de niveau recherche, publiés ou non, émanant des établissements d'enseignement et de recherche français ou étrangers, des laboratoires publics ou privés. 


\title{
Ceramic and metal-ceramic nanostructures obtained by reactive ball milling
}

\author{
J. SECONDI and R. YAVARI
}

LTPCM-CNRS URA 29, Institut National Polytechnique de Grenoble, BP. 75, Domaine Universitaire, 38402 St Martin d'Hères cedex, France

Abstract: We review ceramic and metal-ceramic nanostructures obtained by ball milling. We then report on the formation of titanium nitride by ball milling elemental titanium powder under nitrogen gas and on TiN-copper nanocomposites produced by ball milling a CuTi alloy under $\mathrm{N}_{2}$ gas.

\section{Introduction}

Ceramic-metal composites made using ball milling were first reported by Benjamin[1]. He mechanically mixed the ceramic phase with metallic powders and obtained a dispersion of oxide particles in a superalloy matrix. In milled powders the particle size is determined by the equilibrium between fractures and welding under the milling ball impacts. In the case of powder mixing, the fracture of the ceramic particles is limited by the presence of the metal powder, which embeds the hard phase. Therefore the ceramic agglomerates cannot be broken down below a given size. Producing the ceramic phase in situ by reactive ball milling is a way of obtaining nanoscaled ceramic particles, with a size range from 5 to $50 \mathrm{~nm}$.

\section{Ceramics obtained by Ball Milling}

Several authors have reported on reactive milling of elemental powders with the aim of making only the ceramic phase. Various methods have been used depending on the type of the desired ceramic. For silicides, carbides, borides and sulfides, metallic powders were milled with the appropriate element. In the case of nitrides the powders were milled under an atmosphere containing nitrogen $\left(\mathrm{N}_{2}, \mathrm{NH}_{3}\right)$.

Depending on the systems and the milling conditions, different ways for obtaining ceramics have been brought to light. The resulting powders can be amorphous or supersaturated solutions, in which the ceramic appears by annealing. They can also be nanocrytalline. This may be explained in some cases by the often used high energy milling conditions, which results is a significant increase in temperature.

Many systems have been studied for their ability to form fully or partially amorphous phases. Examples are : Ta-Si, V-Si[2], Ti-Si[3], Fe-Si[4, 5],Fe-CSi[6], Ge-Si[7], Sn-Si, Zn-Si[8], Fe-B[9],Cr$\mathrm{B}[10], \mathrm{NdFe}-\mathrm{B}[11], \mathrm{Si}-\mathrm{C}, \mathrm{Si}-\mathrm{B}[12]$, AlTa-N[13], B-N[14]. Formation of nanocrystalline mixtures were reported in : $\mathrm{Fe}-\mathrm{Si}[15], \mathrm{NdFe}-\mathrm{B}[11], \mathrm{Fe}-\mathrm{B}[16], \mathrm{Nb}-\mathrm{Si}[17]$. In $\mathrm{Nb}-\mathrm{Si}$ formation of the $\mathrm{Nb}_{5} \mathrm{Si}_{3}$ compound is due to the exothermicity of the reaction. In some systems, the ceramic compound is obtained after annealing : $\mathrm{FeB}$ with $\mathrm{Fe}_{2} \mathrm{~B}[9], \mathrm{NdFeB}[11], \mathrm{FeSi}_{2}[15]$, $\mathrm{Ti}_{5} \mathrm{Si}_{3}[18]$. Incomplete transformations have also been reported with ceramic phases coexisting with nanocrystalline or amorphous phases : Fe-B[9], TiB[18], Si-C[12], Si-N, W-N, Cr-N[14], Fe-N[19, 20]. The non-appearance of the ceramic phase or its coexistence with another phase is in part explained by the non-stochiometry of the milled powders, and at stochiometry, it is attributed to low energy milling conditions, which prevent large temperature increases required for crystallisation of the amorphous as-milled product. 
Many single phase ceramics have also been obtained directly by ball milling : $\mathrm{VSi}_{2}, \mathrm{NbSi}_{2}, \mathrm{Nb}_{5} \mathrm{Si}_{3}$ and $\mathrm{TaSi}_{2}[2]$, TiSi2 $2 \mathrm{NiSi}, \mathrm{WC}_{\mathrm{x}}[18], \mathrm{Cr}_{3} \mathrm{C}_{2}, \mathrm{Mn}_{3} \mathrm{C}[21,22], \mathrm{Fe}_{3} \mathrm{C}[21-23], \mathrm{Co}_{3} \mathrm{C}[21,22,24], \mathrm{Fe}_{7} \mathrm{C}_{3}[6$, 22, 23], TiC, $\mathrm{ZrC}_{\mathrm{X}}, \mathrm{HfC}, \mathrm{Fe}_{2}, \mathrm{MoCx}, \mathrm{Al}_{4} \mathrm{C}_{3}, \beta-\mathrm{SiC}[22], \mathrm{Ni}_{3} \mathrm{C}[22,24], \mathrm{VC}, \mathrm{V}_{2} \mathrm{C}[22,25], \mathrm{NiS}, \mathrm{ZnS}$, $\mathrm{FeS}[26], \mathrm{NdB}[10], \mathrm{TiB}_{2}[27], \mathrm{VN}, \mathrm{ZrN}, \mathrm{AIN}, \mathrm{Cu}_{3} \mathrm{~N}, \mathrm{Mg}_{3} \mathrm{~N}_{2}[14], \mathrm{TiN}[14,28], \mathrm{Ti} 2 \mathrm{~N}[19]$ ]. At least, the formation of the following complex carbides and nitrides by ball milling was also reported : $\mathrm{TaReC}_{2}$, $\mathrm{FeW}_{3} \mathrm{C}, \mathrm{Ti}_{0.885} \mathrm{Al}_{0.104} \mathrm{~V}_{0.036} \mathrm{C}, \mathrm{NbTaMoReC}_{4}[22]$, (TiAl)N $[29,30]$ as well as a carbide from a $\mathrm{Ti}-\mathrm{Al}$ alloy milled with n-heptane[31].

Calka et al.[25] showed the importance of milling conditions for the formation of vanadium carbides ( $\mathrm{VC}$ and $\mathrm{V}_{2} \mathrm{C}$ ). When using high energy ball milling, the resulting carbides were found to be nanocrystalline. Lower energy conditions gave a vanadium-carbon mixture, which crystallized into the carbides upon annealing. It was explained later [32] that the pressure, evaluated at $40 \mathrm{kbar}$ during ball collisions, was preventing the crystallization of the carbide, while high temperatures attained in high energy milling led to the carbides crystallization.

\section{Ceramic-Metal Composites Obtained by Ball Milling}

The possibility of making the ceramic in situ was shown in 1989 by Luton et al.[33] using a reaction between the milled powder and the milling environement. Aluminum alloys were reinforced by an aluminum oxy-nitride phase obtained by slury milling in liquid nitrogen. In a similar way, Whittenberger et al.[34] obtained a NiAl-AlN composite by ball milling the NiAl compound in liquid nitrogen. Following the same principle but milling under nitrogen atmosphere, Ogino et al.[29] obtained a composite of titanium nitride mixed with iron from a Ti ${ }_{50} \mathrm{Fe}_{50}$ mixture. It was also found that ball milling of copper alloys in air results in the formation of oxide-copper composites[35].

We have produced titanium nitride by ball milling a titanium powder under nitrogen atmosphere. We have also used the ability of titanium to be nitrided for synthesizing directly a metal-ceramic composite[36]. Copper titanium alloys were milled under nitrogen atmosphere to obtain titanium nitride nanodispersions in a copper matrix.

\section{Experimental Procedure}

Titanium nitride was prepared by ball milling titanium elemental powder in a Fritsch "pulverisette" vibrating mill under $\mathrm{N}_{2}$ gas [35]. The powder was milled gram per gram at different milling times with a ball-to-powder ratio of 500 . Nitrogen was introduced in the vial after 12 hours of pre-milling under dynamic primary vacuum performed in order to nanocrystallize the pure titanium powder.

For making the composite, a $\mathrm{Ti}_{17} \mathrm{Cu}_{83}$ alloy was first prepared by induction melting and subsequently melt spun. The melt-spun ribbons, which were microcrystalline fcc, were then milled under nitrogen atmosphere in the same mill and energetic conditions as used for the titanium. The atmosphere was also controlled by making a primary vacuum before filling with nitrogen. The milled powders have been characterized by $\mathrm{X}$-ray diffraction performed on a Siemens diffractometer using $\mathrm{Cu}-\mathrm{K} \alpha_{1}$ radiation and TEM observations on a Jeol $200 \mathrm{CX}$ microscope

The X-ray diffraction patterns have been analysed in order to determine the diffracting domain size and heterogeneous strain. The Williamson-Hall method for the analysis of line broadening is appropriate for isotropic particle shapes. But in the case of copper, this method can only be applied to the 111 and 222 reflections in order to avoid the anisotropy problem. The degraded stastistics of the 222 reflection constrained us to use a one peak method, described by De Keijser et al[37]. 
These authors fit a diffraction peak to a Voigt function, which is the convolution of Cauchy and Gaussian functions. They assume that the Cauchy and Gaussian contributions arise respectively from coherent domain size and heterogeneous strain. Langford[38] showed how to determine the Cauchy $\beta C$ and Gaussian $\beta_{\mathrm{G}}$ integral breadths from the Voigt fit parameters. After correction for removing instrumental broadening[37], the grain size D and the heterogeneous strain $\varepsilon$ are estimated from the corrected values $\beta_{C}^{c}$ and $\beta_{\mathrm{G}}^{\mathrm{c}}$ by :

$$
D=\frac{\lambda}{\beta_{C}^{c} \cdot \cos (\theta)} \quad \text { and } \quad \varepsilon=\frac{\beta_{G}^{c}}{4 \cdot \tan (\theta)}
$$

where $\lambda$ is the wavelength and $\theta$ the Bragg angle.

$\mathrm{X}$-ray diffraction was also used for monitoring the evolution of the copper phase lattice parameter. A silicon reference powder was added in small amounts to each powder sample for removing the eccentricity error. This error is due to a shift $\Delta \mathrm{l}$ between the sample and the goniometer center. The peak displacement $\Delta 2 \theta$ is a function of $\theta$ :

$$
\Delta 2 \theta=\frac{\Delta l}{\mathrm{R}} \cdot \frac{\sin (2 \theta)}{\sin (\theta)}
$$

where $\mathrm{R}$ is the goniometer radius. The position of a silicon reflection allows estimation of the ratio $\Delta l / \mathrm{R}$ and then the correction for other reflections. The latrice parameter value is then calculated from each peak position using Bragg's law.

The unit-cell values, for the first four reflections in our case, are subsequently fitted linearly as a function of $\frac{1}{2}\left[\frac{\cos ^{2}(\theta)}{\sin (\theta)}+\frac{\cos ^{2}(\theta)}{\theta}\right]$. Following Nelson et al.[39], the optimized value is then obtained by extrapolation to $\theta=0$ in order to remove the absorption errors. The determination accuracy is estimated to be $\pm 5 \cdot 10^{-3} \AA$.

\section{Results and Discussion}

The monitoring of titanium's nitridation is showed on fig.1. For titanium milled 12 hours in vacuum, the hexagonal lattice parameters, calculated on the 002 and 101 reflexion, are close to that of ASTM with $\mathrm{a}=2.94 \AA$ and $\mathrm{c}=4.69 \AA$. A small amount of amorphous phase may be present due to a partial oxidation. After 6 hours of milling in nitrogen, the parameter c increases to $4.71 \AA$ while a is constant. After 14 hours, the appearance of titanium nitride prevents further quantitative analysis of the Ti patterns.

After 18 and 24 hours of milling under nitrogen, the TiN phase appears clearly. There is still a remaining trace of titanium phase and a larger iron contamination from the vial occurs. The TiN lattice parameter, estimated from the 111 reflection increases from $4.22(18 \mathrm{~h})$ to $4.24 \AA$ ( $24 \mathrm{~h})$, indicating a $10 \%$ increase in nitrogen content[40]. The de Keijser analysis on the 111 reflection indicates that grain size is around $4 \mathrm{~nm}$, while heterogeneous strain is low with $\varepsilon \approx 16$ and $21 \times 10^{-3}$ after 18 and 24 hours of milling under nitrogen.

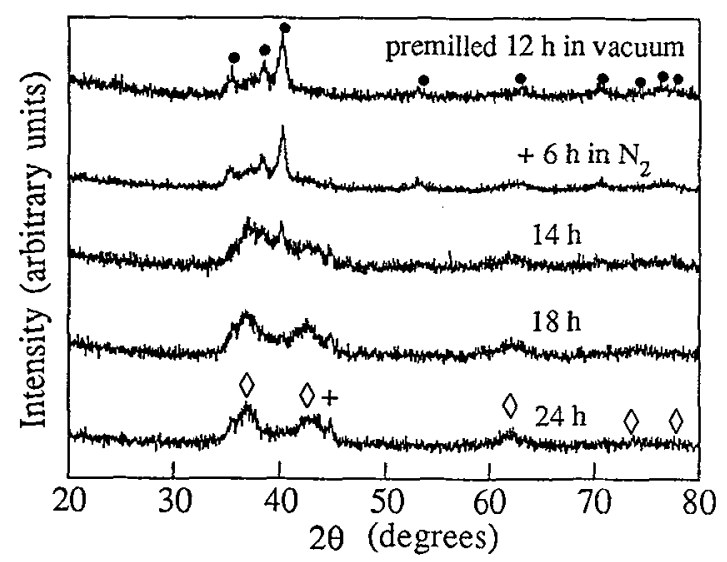

Fig. 1: X-ray diffraction patterns of titanium (•) powder milled under nitrogen atmosphere. After 18 hours, the TiN phase $(\theta)$ is the principal phase. Significant iron $(+)$ contamination is also detected. 
Fig.2 presents a TEM dark field image of the 18 hours milled powder using the 111 and 200 TiN reflections and its corresponding electron diffraction pattern. The grain size is confirmed to be 3 to $5 \mathrm{~nm}$. The largest grains attain $10 \mathrm{~nm}$. We note that the remaining titanium and the iron contamination are not seen on the diffraction pattern. This may be explained by the small size of the observed zone, which could not be representative of the powder.

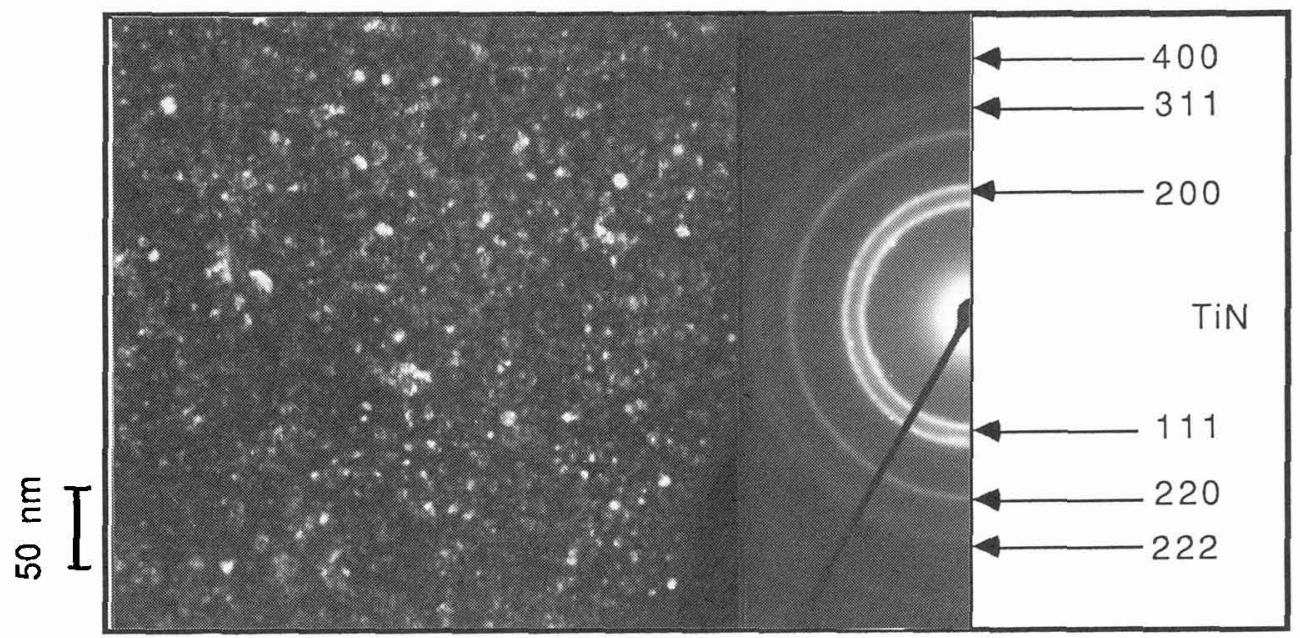

Fig. 2: TEM electron diffraction pattem of the titanium powder milled 18 hours under nitrogen and dark field.image using the 111 and 200 reflections.

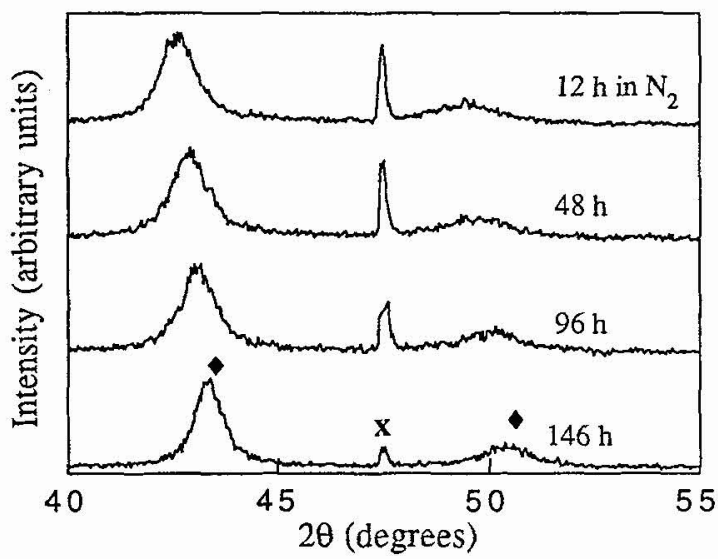

Fig. 3: X-ray diffraction patterns of fcc $\mathrm{Cu}_{83} \mathrm{Ti}_{17}$ milled under nitrogen atmosphere. The TiN peaks cannot be seen because of its low structure factor. ( indicates the near pure copper peak positions and $(\mathbf{x})$ is the silicon reference powder.
Fig. 3 presents the evolution of $x$-ray diffraction patterns for the Cu83 $\mathrm{Ti}_{17}$. From these spectra the optimized lattice parameters, grain size and heterogeneous deformation were calculated as described earlier. The results are presented in fig. 4 . The first point at $t=0$ represents in fact the ribbons milled under argon for 48 hours. After 12 hours of milling under nitrogen, a large increase of the parameter from 3.64 to $3.69 \AA$ is observed. This shows that presence of titanium increases the nitrogen solubility in copper. A progressive decrease of the lattice parameter is then observed with continued milling. This indicates that nitridation removes the titanium from the copper alloy. At the end of milling, some titanium is still present in the copper, whose lattice parameter of $3.625 \AA$ is still about $0.3 \%$ larger than that of pure copper.

Simultaneously, the grain size, as determined from the fcc- 111 reflection decreases from 9 to $8 \mathrm{~nm}$ and then goes back up to $11 \mathrm{~nm}$. At the same time, the heterogeneous strain level first increases from 9 to $11 \times 10^{-3}$ and then decreases to $8 \times 10^{-3}$. If the first step is not yet fully understood, it seems clear that the grain size increase is a consequence of the softening of the fcc copper alloy due to the reduction of its titanium content[41]. 

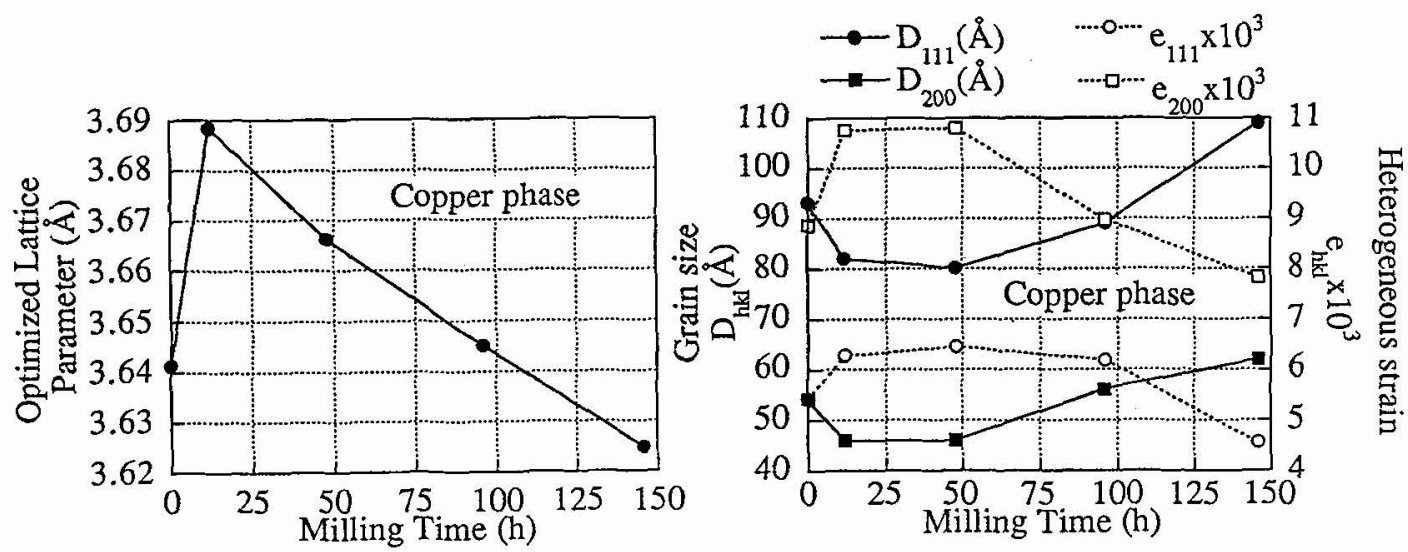

Fig. 4: The evolution of optimized lattice parameter, grain size and heterogeneous strain with milling time as derived from the 111 and 200 reflections of $\mathrm{fcc}_{\mathrm{C}} \mathrm{Cu}_{33} \mathrm{Ti}_{17}$ milled under nitrogen atmosphere.

TEM dark field observations were also performed on the final milled powder. Electron diffraction (fig.5) shows the existence of the TiN phase, which could not be seen with $x$ rays because of its low structure factor. The TEM dark field image for the $\mathrm{Cu}-220$ reflection shows largest copper grain sizes around $10 \mathrm{~nm}$. Another image obtained from the Cu-111 and TiN-200 reflections showed a maximum grain size around $20 \mathrm{~nm}$, presumed to be that of copper. This is consitent with $\mathrm{x}$-ray observations, which gave the average grain sizes of 7 and $11 \mathrm{~nm}$ for the $\mathrm{Cu}-220$ and $\mathrm{Cu}-111$ reflections respectively, and confirms the shape anisotropy of copper grains. The largest TiN grains, observed with the TiN-220 reflection, attained $10 \mathrm{~nm}$.

\section{Conclusion}

Nanoceramics and cermets can be prepared by ball milling. In the particular case of reactive ball milling under $\mathrm{N}_{2}$ gas, both titanium nitride and TiN-noble metal nanocomposites can be obtained from pure $\mathrm{Ti}$ and $\mathrm{Ti}$-noble metal alloys respectively.

\section{Acknowledgment}

We thank O. Drbohlav for useful discussions on the exploitation of $\mathrm{x}$-ray diffraction patterns.

[1]. J.S. Benjamin, Sci. Am. 234 (1976) 40-48.

[2]. R.K. Viswanadham, S.K. Mannan, S. Kumar, Scripta Metal. 22 (1988) 1011-10-14.

[3]. A. Calka, A.P. Radlinski, R.A. Shanks, A.P. Pogany, J. Mater. Sci. Let. 10 (1991) 734-737

[4]. E. Gaffet, N. Malhouroux, M. Abdellaoui, J. Alloys and Compounds to be published. 
[5]. V.E. Martin, A. Garcia-Escorial, A. Martin, F. Carmona, F. Cebollada, P. Adeva, J.M. Gonzales, J. de Phys. C4, suppl. 14, (1990) 197-203.

[6]. T. Tanaka, S. Nasu, K. Nakagawa, K.N. Ishihara, P.H. Shingu, Mater. Sci. For. 88-90 (1992) 269-274.

[7]. E. Gaffet, F. Faudot, M. Harmelin, Mater. Sci. For. 88-90 (1992) 375-382.

[8]. E. Gaffet, M. Harmelin, J. de Phys. C4, suppl. 14, (1990) 139-150.

[9]. A. Calka, A.P. Radlinski, Appl. Phys. Lett. 58[2] (1991) 119-121.

[10]. M.A. Morris, D.G. Morris, J. de Phys. C4, suppl. 14, (1990) 211-217.

[11]. L. Schutz, J. Wecker, E. Hellstern, J. Appl. Phys. 61[8] (1987) 3583-3585.

[12]. E. Gaffet, P. Marco, M. Fedoroff, J.C. Rouchaud, Mater. Sci. For. 88-90 (1992) 383-390.

[13]. M.S. El-Eskandarany, K. Aoki, K. Suzuki,, Appl. Phys. Lett. 60[13] (1992) 1562-1563.

[14]. A. Calka, J.S. Williams, Mater. Sci. For. 88-90 (1992) 787-795.

[15]. N. Malhouroux-Gaffet, E. Gaffet, J. Alloys and Compounds, to be published.

[16]. S. Surinach, M.D. Baro, J. Segura, N. Clavaguera, M.T. Clavaguera-Mora, Mater. Sci. For. $88-90$ (1992) 275-282.

[17]. J. Kajuch, K. Vedula, Adv. Pow. Met. 2 (1990) 187-205.

[18]. A.P. Radlinski, A. Calka, Mater. Sci. Eng. A134 (1991) 1376-1379.

[19]. M.S. El-Eskandarany, K.Sumiyama, K. Aoki, K. Suzuki, Mater. Sci. For. 88-90 (1992) $801-808$.

[20]. T. Koyano, C.H. Lee, T. Fukunaga, U. Mizutani, Mater. Sci. For. 88-90 (1992) 809-816.

[21]. G. Le Caër, E. Bauer-Grosse, A. Pianelli, E. Bouzy, P. Matteazzi, J. Mater. Sci. 25 (1990) 4726-4731.

[22]. P. Matteazzi, G. Le Caër, J. Am. Ceram. Soc. 74[6] (1991) 1382-1390.

[23]. T. Tanaka, S. Nasu, K.N. Ishihara, P.H. Shingu, J. Less-Common Metals 171 (1991) 237-247.

[24]. T. Tanaka, K.N. Ishihara, P.H. Shingu, Metal. Trans. 23A (1992) 2431-2435.

[25]. A. Calka, W.A. Kaczmarek, Scripta Metal. 26 (1992) 249-253.

[26]. T. Kosmacs, T.H. Courtney, J. Mater. Res. 7[6] (1992) 1519-1525.

[27]. A. Calka, A.P. Radlinski, J. Less-Common Metals 161 (1990) L23-L26.

[28]. M.S. El-Eskandarany, K.Sumiyama, K. Aoki, K. Suzuki, J. Mater, Res. 7[4] (1992) 888-893.

[29]. Y. Ogino, M. Miki, T. Yamasaki, T. Inuma, Mater. Sci. For. 88-90 (1992) 795-800.

[30]. Y. Ogino, T. Yamasaki, M. Miki, N. Atsumi, K. Yoshioka, Scripta Metal. 28 (1993) 967-971.

[31]. T. Suzuki, M. Nagumo, Scripta Metal. 27 (1992) 1413-1418.

[32]. A. Calka, J.S. Williams, Scripta Metal. 27 (1992) 999-1004.

[33]. M.J. Luton, C.S. Jayanch, M.M. Disko, S. Matras, J. Vallone, Mat. Res. Soc. Symp. Proc. 132 (1989) 7986.

[34]. J. D. Whittenberger, M.J. Luton, J. Mater. Res. 7[10] (1992) 2724-2732.

[35]. J. Secondi, Thèse INPG 1994, to be published.

[36]. J. Secondi, R. Yavari, Int. Symp. "Metastable Phase Formation in the Solid State", Irsee, July 1992, unpublished.

[37]. Th.H. De Kejser, J.I. Langford, E.J. Mittemeijer, A.B.P. Vogels, J. Apl. Cryst. 15 (1982) 308-314.

[38]. J.I. Langford, J. Apl. Cryst. 11 (1978) 10-14.

[39]. J.B. Nelson, D.P. Riley, Proc. Phys. Soc. London 57 (1945) 160-177.

[40]. H.A. Wriedt, J.L. Murray, Bull. Alloy Phase Diagr. 8[4] (1987) 378-388.

[41]. J. Eckert, J.C. Holzer, C.E. Krill III, W.L. Johnson, J. Mater. Res. 7 (1992) 1980-1983. 